\title{
Development in broaching technology Part III. Directions of experimental investigations of broaching process and broach design
}

\author{
Postęp w obróbce przeciąganiem \\ Część III. Kierunki badań doświadczalnych przeciągania \\ i projektowania przeciągaczy
}

WIT GRZESIK *

DOI: https://doi.org/10.17814/mechanik.2021.10.14

\begin{abstract}
The paper structured into three parts outlines the present state of the broaching technology. The first part (Mechanik 5-6, 2021) highlighted possible process variants for internal and external operations and designs of broaching machines as well as CNC control systems and other advanced automatization forms. The second part (Mechanik 8-9, 2021) was devoted to the progressive broaching methods such as rotary broaching, hard broaching and MQL application. The third part discusses some important directions of experimental investigations carrying out for more efficient and reliable broaching processes.
\end{abstract}

KEYWORDS: broaching technology, broaching machines, broaching tools

Artykuł prezentuje aktualny stan obróbki przeciąganiem z podziałem na trzy części. W pierwszej części (Mechanik 5-6, 2021) opisano odmiany procesu i konstrukcje obrabiarek ze szczególnym uwzględnieniem napędu ruchu głównego, sterowania CNC i zaawansowanych form automatyzacji. W drugiej części (Mechanik 8-9, 2021) dokonano przeglądu sposobów przeciągania, takich jak przeciąganie obrotowe, materiałów utwardzonych i obróbka MQL. Trzecia część omawia ważne kierunki prowadzonych badań doświadczalnych procesu przeciągania.

SŁOWA KLUCZOWE: przeciąganie, przeciągarki, przeciągacze

\section{Wprowadzenie}

Przeciąganie należy do sposobów obróbki skrawaniem, w których zasadniczo jako narzędzie kształtowe stosuje się przeciągacz o budowie jednolitej lub składanej oraz zespoły przeciągaczy. Naddatek obróbkowy jest usuwany kolejno przez pojedyncze ostrza lub grupę ostrzy o podobnej geometrii, w trybie warstwa po warstwie, ze stałą prędkością. W pierwszej części artykułu [1] opisano odmiany procesu przeciągania i konstrukcje obrabiarek. Druga część artykułu [2] była poświęcona rozwojowi sposobów przeciągania i oprzyrządowania narzędziowego na obrabiarkach CNC.

\section{Przegląd badań procesu przeciągania}

Jak wspomniano w pierwszej części artykułu [1], poziom automatyzacji i sterowania $\mathrm{w}$ procesie przecią- gania w latach 2005-2010 - czyli w okresie intensywnego rozwoju sterowania CNC, oprogramowania CAD/ /CAM i serwonapędów - wyraźnie odbiegał od osiągnięć w toczeniu, frezowaniu czy wierceniu. Obecnie wiele firm produkujących przeciągarki i oprzyrządowanie narzędziowe inwestuje w rozwój przeciągania, ponieważ jest ono jednym z najszybszych i najdokładniejszych sposobów obróbki złożonych powierzchni zewnętrznych i wewnętrznych [3-5]. Tym samym pojawiła się konieczność prowadzenia badań doświadczalnych i symulacji numerycznych procesu, zwłaszcza w warunkach przestrzennego stanu odkształcenia (3D), czyli skrawania ukośnego. Takie przypadki zostaną tu omówione. Należy podkreślić, że przeciąganie traktuje się zwykle jako przypadek skrawania dwuwymiarowego (ortogonalnego) [6]. Ważnym czynnikiem jest uwzględnienie przeciągania $w$ takich strategiach, jak inteligentne wytwarzanie (smart manufacturing), Internet Rzeczy (IoT) czy Przemysł 4.1 (Industry 4.1).

\section{Metodologia i zakres badań doświadczalnych}

Proces przeciągania jest zasadniczo badany w trzech komplementarnych odmianach: wewnętrzny, zewnętrzny i pojedynczym ostrzem [3, 7]. Poszczególne przypadki wraz z zakresem pomiarów i stosowanym oprzyrządowaniem przedstawiono na rys. $1 a-c$.

Przypadek przeciągania wewnętrznego (rys.1a), chociaż najczęściej występuje w praktyce przemysłowej, ma istotne ograniczenia ze strony badawczej i pomiarowej, przede wszystkim dlatego, że uniemożliwia pomiar siły odporowej, gdy np. stosuje się przeciągacze z ostrzami śrubowymi. Dodatkowo nie ma możliwości wizualizacji i monitorowania procesu tworzenia wióra, który - jak wykazano w drugiej części artykułu [2] - jest ważnym kryterium optymalizacji procesu.

Tego ograniczenia nie ma w przeciąganiu zewnętrznym narzędziem z wieloma ostrzami (rys. $1 b$ ). Oprócz możliwości pomiaru obciążenia promieniowego narzędzia występuje ułatwiony dostęp do strefy obróbki takich urządzeń pomiarowych, jak kamera do szybkiego filmowania tworzenia wióra, kamera na podczerwień (IR camera) i pirometry do pomiaru temperatury. Z kolei dość istotnym ograniczeniem jest uwzględnienie $w$ badaniach naddatku na jedno ostrze

\footnotetext{
* Prof. dr hab. inż. Wit Grzesik, w.grzesik@po.edu.pl, https://orcid.org/0000-0003-3898-5119 - Katedra Technologii Maszyn
} i Materiałoznawstwa Politechniki Opolskiej, Opole, Polska 


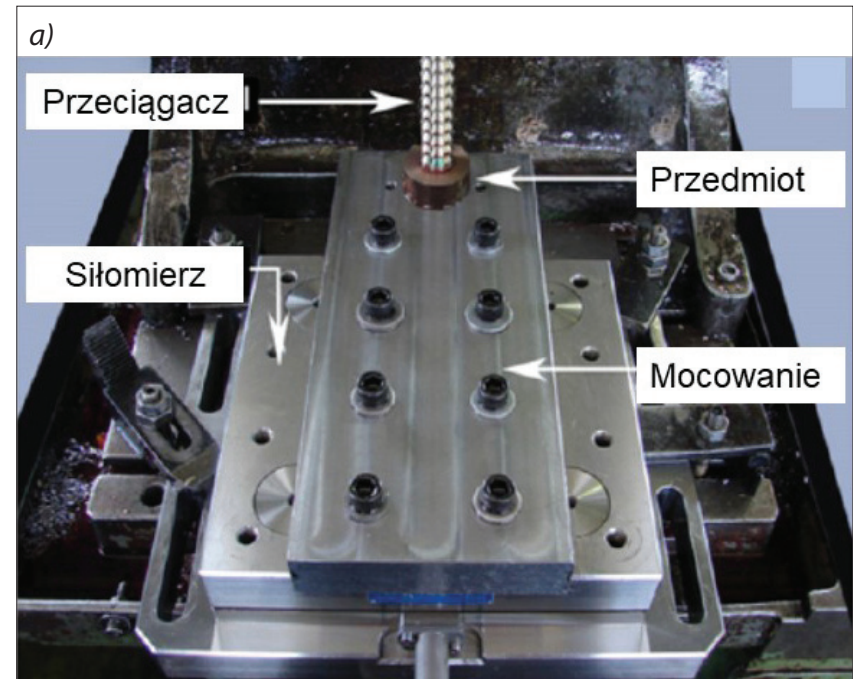

b)

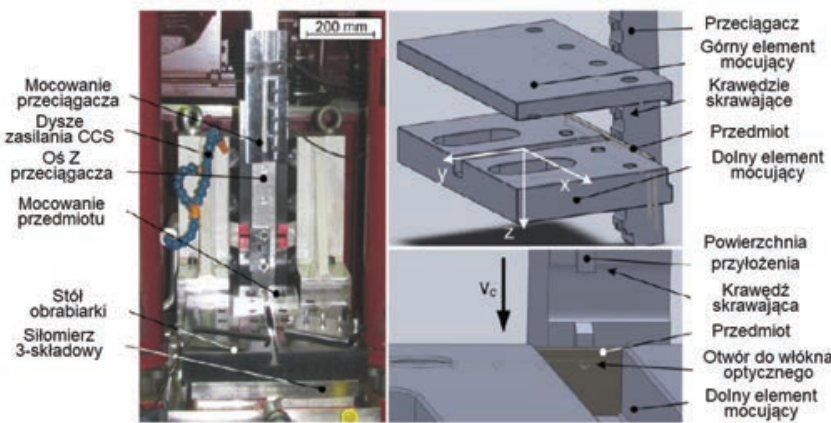

c)

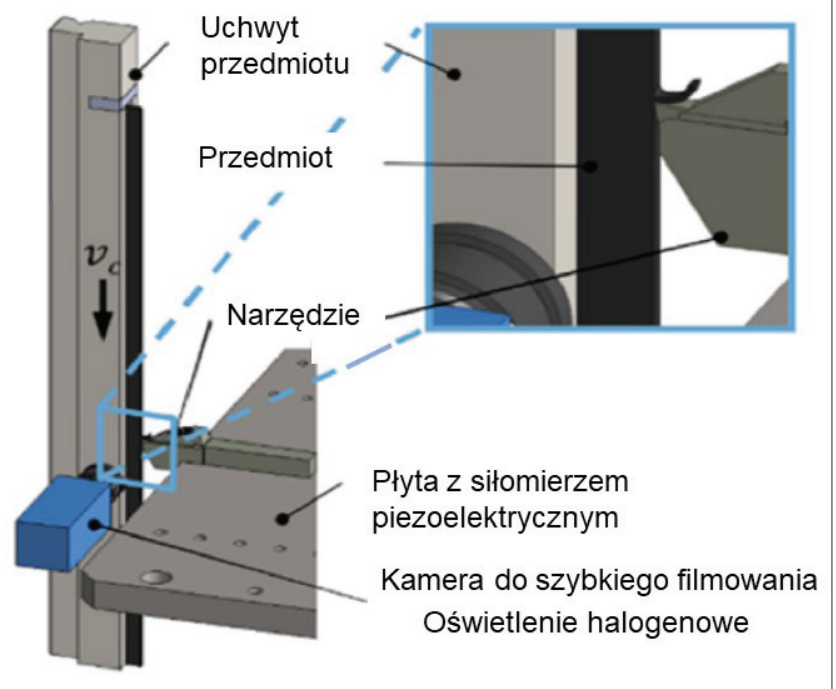

Fig. 1. Typical variants of the broaching process investigated: $a$ ) internal, b) external and $c$ ) with a single tooth $[3,7,8]$

Rys. 1. Odmiany procesu przeciągania uwzględniane w badaniach doświadczalnych: $a$ ) wewnętrzne, $b$ ) zewnętrzne i c) pojedynczym ostrzem $[3,7,8]$

(ważne podczas projektowania narzędzia) i z tego powodu konieczne jest stosowanie zestawu przeciągaczy o różnym wymiarze ostrzy.

Trzecia odmiana, oparta na przeciąganiu pojedynczym ostrzem (rys. 1c), wydaje się najbardziej uniwersalna i elastyczna. Umożliwia szybkie filmowanie tworzenia wióra kamerą z dodatkowym oświetleniem halogenowym oraz pomiar sił za pomocą siłomierza piezoelektrycznego usytuowanego na płycie przemieszczającej się do góry (jak w przeciągarkach typu vertical pull-down broaching).
Wymienione przypadki badania procesu przeciągania są stosowane do obróbki części w przemyśle motoryzacyjnym (ze stali w gatunkach: AISI 5115, AISI 5120, AISI 1045), energetycznym (ze stali odpornych na korozję w gatunku AISI 410) i lotniczym (ze stopów tytanu i niklu stosowanych na elementy turbin/sprężarek silników lotniczych) [3, 7].

\section{Przykłady wyników badań doświadczalnych procesu przeciagania}

Podstawowe badania procesu przeciągania dotyczą rejestracji cyklu tworzenia wióra, pomiaru temperatury i obciążeń mechanicznych.

Problem tworzenia wióra jest jednym z ważniejszych czynników decydujących o przebiegu procesu przeciągania (głównie jego stabilności i wydajności). Wiór powinien być dokładnie zwijany w rowku i nie jest dopuszczalne jego łamanie, jak np. w toczeniu. Aby zapewnić tworzenie ciągłego i zwartego wióra, stosuje się duże dodatnie kąty natarcia.

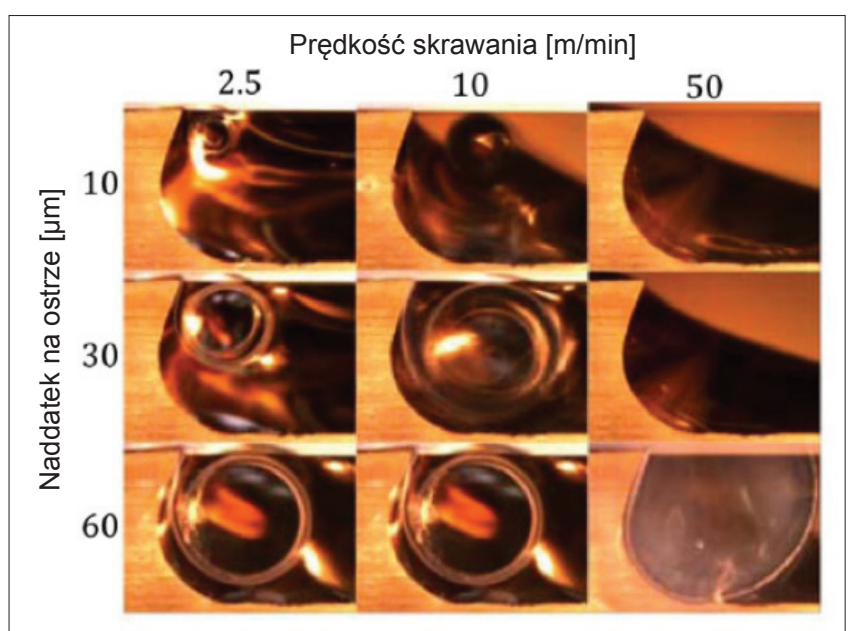

Fig. 2. Visualization of chip formation and curling in external broaching of X12Cr13 alloy steel [3]

Rys. 2. Wizualizacja tworzenia i zwijania wióra w przeciaganiu zewnętrznym stali stopowej X12Cr13 [3]

Czynnikami, które wpływają na przebieg zwijania wióra i jego kształt, są prędkość skrawania i naddatek (przyrost grubości warstwy skrawanej) na ostrze, jak na rys. 2. Problem doboru tych parametrów polega na uzyskaniu mniejszej krzywizny wióra, co gwarantuje jego lepsze wypełnienie w rowku wiórowym (chip nesting). Należy dodać, że wzrost naddatku na ostrze nie tylko powoduje wzrost krzywizny wióra, ale też utrudnia zginanie bardziej sztywnych wiórów. Trzeba mieć na uwadze zależność wydajności procesu od wartości tych parametrów. W przypadku wzrostu ich wartości konieczne jest uwzględnienie wytrzymałości ostrza i możliwości jego uszkodzenia mechanicznego. Zakleszczaniu się wiórów w rowkach można zapobiegać poprzez dodatkowe zabiegi, np. czyszczenie rowka szczotką czy cieczą pod wysokim ciśnieniem.

Na rys. 3 przedstawiono wpływ różnych czynników powodujących przyrosty wartości siły skrawania $\left(F_{\mathrm{c}}\right)$ (rys. $3 a$ ) i siły promieniowej $\left(F_{\mathrm{r}}, F_{\mathrm{cN}}\right)$ (rys. $3 b$ ) w obróbce stopów niklu i tytanu. W przypadku siły 


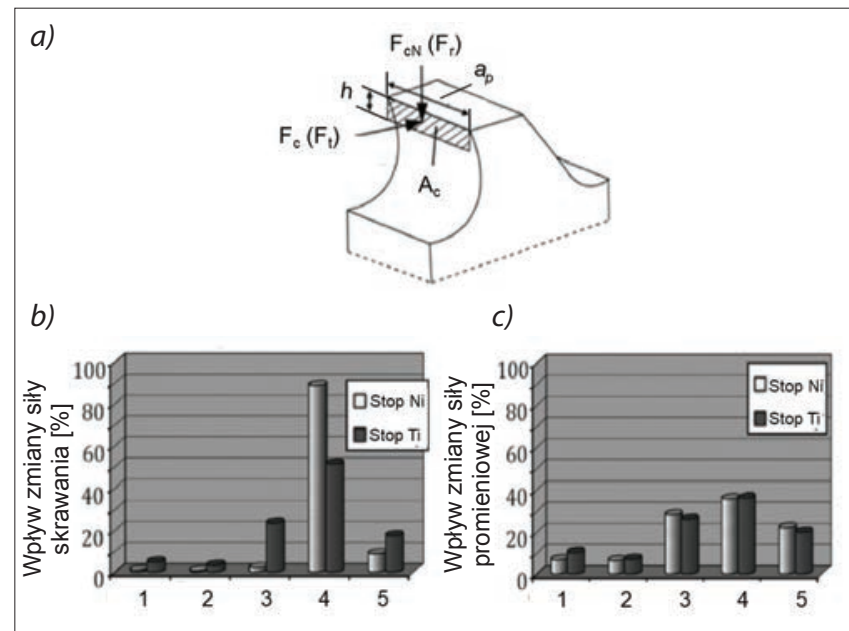

Fig. 3. Scheme of mechanical loading of a single tooth $(a)$ and the influence of process variables on cutting $(b)$ and radial $(c)$ forces. 1 - cooling liquid, 2 - cutting speed, 3 - rake angle, 4 - cutting allowance, 5 - error [3]

Rys. 3. Schemat obciążenia pojedynczego ostrza (a) oraz wpływ czynników zmiennych na: $b$ ) siłę skrawania i c) siłę promieniową. 1 - ciecz chłodząca, 2 - prędkość skrawania, 3 - kąt natarcia, 4 - naddatek na ostrze, 5 - błąd [3]

skrawania decydującym czynnikiem jest naddatek na ostrze, natomiast $\mathrm{w}$ przypadku siły promieniowej - również kąt natarcia, ale ich wpływ jest mniejszy. Należy zauważyć, że zmiany wartości sił mogą być także wywołane koniecznością stabilizacji systemu $n$ - $u$-o po jego wzbudzeniu w fazie wcięcia ostrza oraz uszkodzeniem rowka wiórowego w czasie zwijania wióra [3]. Ze względu na charakter procesu przeciągania siły składowe są wyznaczane dla każdego z ostrzy, które równocześnie uczestniczą w obróbce. Zwykle są wyznaczane jako siły (opory) właściwe skrawania [6], czyli:

$$
\begin{aligned}
& k_{\mathrm{cc}}=\frac{F_{\mathrm{c}}}{A_{\mathrm{c}}} \\
& k_{\mathrm{ccN}}=\frac{F_{\mathrm{cN}}}{A_{\mathrm{c}}}
\end{aligned}
$$

gdzie: $F_{\mathrm{c}}$ i $F_{\mathrm{cN}}\left(F_{\mathrm{r}}\right)$ - siła skrawania i siła promieniowa, $A_{\mathrm{c}}$ - pole przekroju poprzecznego warstwy skrawanej.

\section{Przykłady wyników modelowania analitycznego i symulacji procesu przeciagania}

Na rys. 4 zaprezentowano wyniki obliczeń oporu właściwego skrawania na podstawie pomiarów składowych sił $F_{\mathrm{c}}$ i $F_{\mathrm{cN}}$ W przeciąganiu stopu Inconel 718 z prędkością skrawania $2 \mathrm{~m} / \mathrm{min}$ i $3 \mathrm{~m} / \mathrm{min}$. Porównano wartości oporu właściwego dla siły skrawania $\left(k_{\mathrm{c} 1.1}\right)$ i siły normalnej $\left(k_{\mathrm{cN} 1.1}\right)$. Grubość warstwy skrawanej była równa $h=0,01 \mathrm{~mm}$ i 0,02 $\mathrm{mm}$. Zastosowano modelowanie analityczne.

Z przedstawionych danych wynika, że opór właściwy skrawania zmniejsza się, gdy wzrastają kąt natarcia (dla stałego kąta przyłożenia $\alpha_{0}=3^{\circ}$ ) i kąt przyłożenia (dla stałego kąta natarcia $\gamma_{\mathrm{o}}=12^{\circ}$ ). W dodatku potwierdzono dobrze znany $\mathrm{w}$ obróbce skrawaniem fakt, że opór właściwy dla większej grubości warstwy skrawanej $h=0,02 \mathrm{~mm}$ jest mniejszy. Wyznaczono następujące równania regresji wielokrotnej:

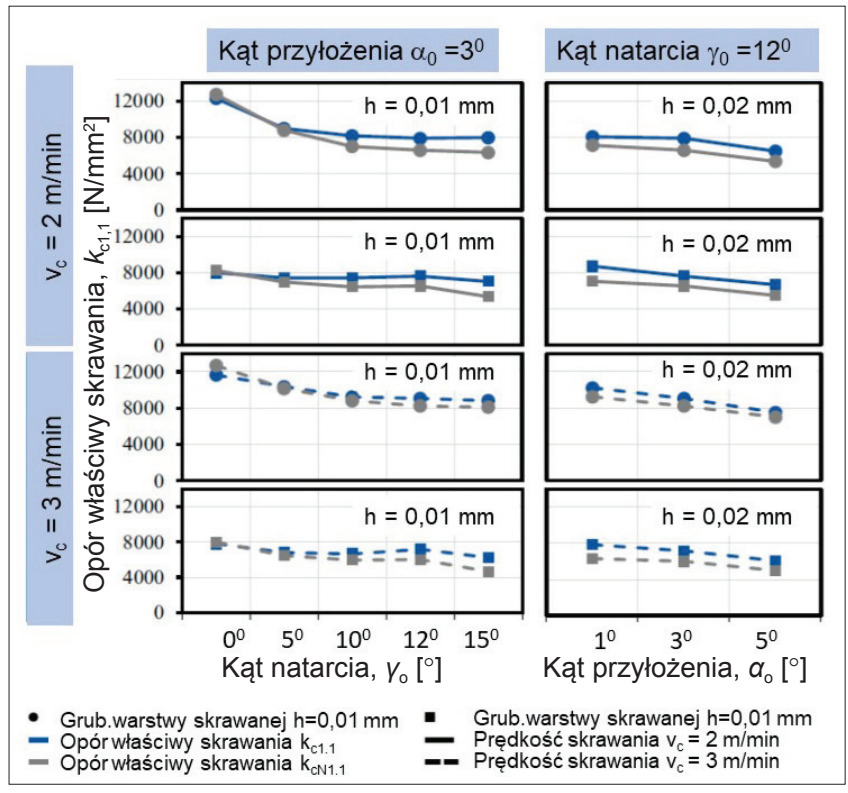

Fig. 4. Simulated values of specific cutting forces in broaching Inconel 718 as function of cutting tool angles [9]. Tool material - high speed steel RexT15

Rys. 4. Symulowane wartości oporu właściwego skrawania w przeciąganiu stopu Inconel 718 w funkcji kątów ostrza [9]. Materiał ostrza - stal szybkotnąca RexT15

$k_{\mathrm{cc}}=13789+178 v_{\mathrm{c}}-208237 h_{\mathrm{i}}-105 \gamma_{\mathrm{oi}}-627 \alpha_{\mathrm{oi}}$

$k_{\mathrm{ccN}}=13958+305 v_{\mathrm{c}}-246898 h_{\mathrm{i}}-223 \gamma_{\mathrm{oi}}-482 \alpha_{\mathrm{oi}}$

gdzie: $k_{\mathrm{cc}}$ i $k_{\mathrm{ccN}}$ - opory właściwe odniesione do siły skrawania i siły normalnej, $v_{c}$ - prędkość skrawania, $h_{\mathrm{i}}$ - lokalny przyrost grubości warstwy skrawanej, $\gamma_{\mathrm{oi}}$ - lokalny kąt natarcia, $\alpha_{\mathrm{oi}}$ - lokalny kąt przyłożenia.

Na rys. 5 przedstawiono wyniki symulacji metodą elementów skończonych, stosując ortogonalny model

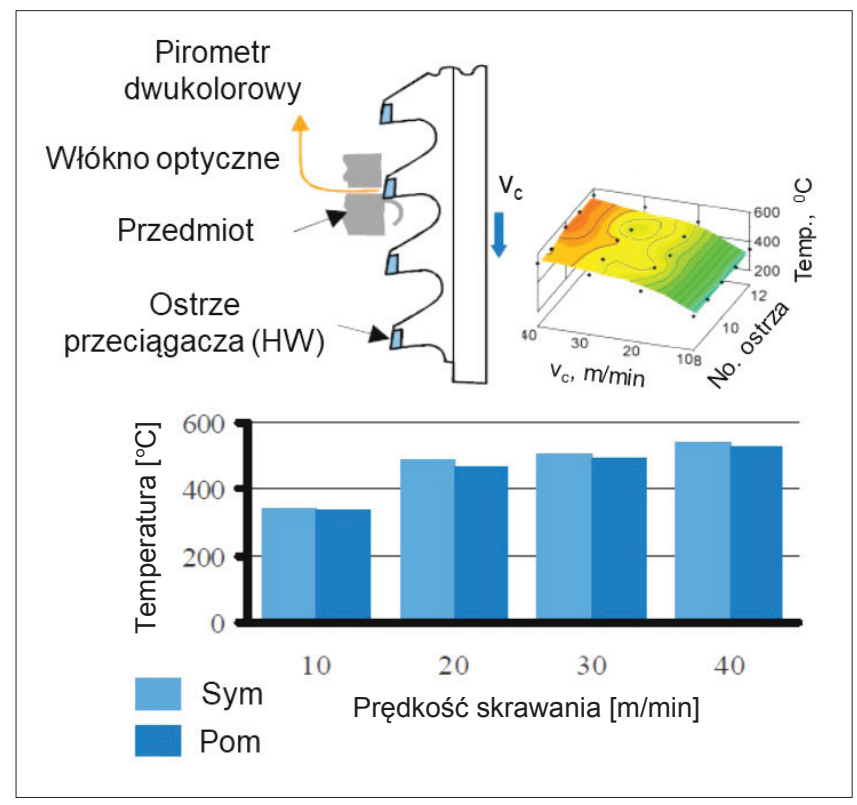

Fig. 5. Comparison of experimental and simulated results of temperature in broaching of forged part from Inconel 718 [8]

Rys. 5. Porównanie zmierzonych i symulowanych wartości temperatury w przeciąganiu zewnętrznym odkuwki ze stopu Inconel 718 [8] 
procesu i model konstytucyjny J-C [8]. Ostrze przeciągacza miało następującą geometrię: kąt natarcia $\gamma_{\mathrm{o}}=0^{\circ}$, kąt przyłożenia $\alpha_{0}=3^{\circ}$, promień zaokrąglenia krawędzi skrawającej $r_{\beta}=30 \mu \mathrm{m}$. Pomiar temperatury przeprowadzono za pomocą pirometru dwukolorowego. Włókno optyczne o średnicy $320 \mu \mathrm{m}$ przeprowadzono przez otwór w przeciąganej próbce do styku z powierzchnią ostrza w czasie przeciągania.

Uzyskano dobrą zgodność wyników pomiaru i symulacji temperatury na powierzchni przyłożenia ostrza w zakresie $300 \div 500^{\circ} \mathrm{C}$. W celu porównania wyników zastosowano model empiryczny do wyznaczenia temperatury na powierzchni przyłożenia w postaci [3]:

$$
T_{\mathrm{obl}}=\sqrt[3]{h} v_{\mathrm{c}}^{0,4} \gamma_{\mathrm{o}}^{-0,15} \sqrt{k_{\mathrm{cc}}}
$$

gdzie: $h$ - grubość warstwy skrawanej, $v_{c}$ - prędkość skrawania, $k_{\mathrm{cc}}$ - opór właściwy skrawania, $\gamma_{\mathrm{o}}$ - ortogonalny kąt natarcia.

Na rys. 6 zaprezentowano koncepcję modelu 3D FE opracowaną $w$ programie symulacyjnym ABAQUS Explicit z zastosowaniem sprzężonej metody Eulera-Lagrange'a (CEL-coupled Eulerian-Lagrangian). Wyniki symulacji odniesione do siły skrawania i siły normalnej z uwzględnieniem zmiany promienia zaokrąglenia krawędzi skrawającej $\left(r_{\beta}\right)$ i zużycia na powierzchni przyłożenia $V B_{\mathrm{B}}$ przedstawiono na rys. $7 a$ i $7 b$.

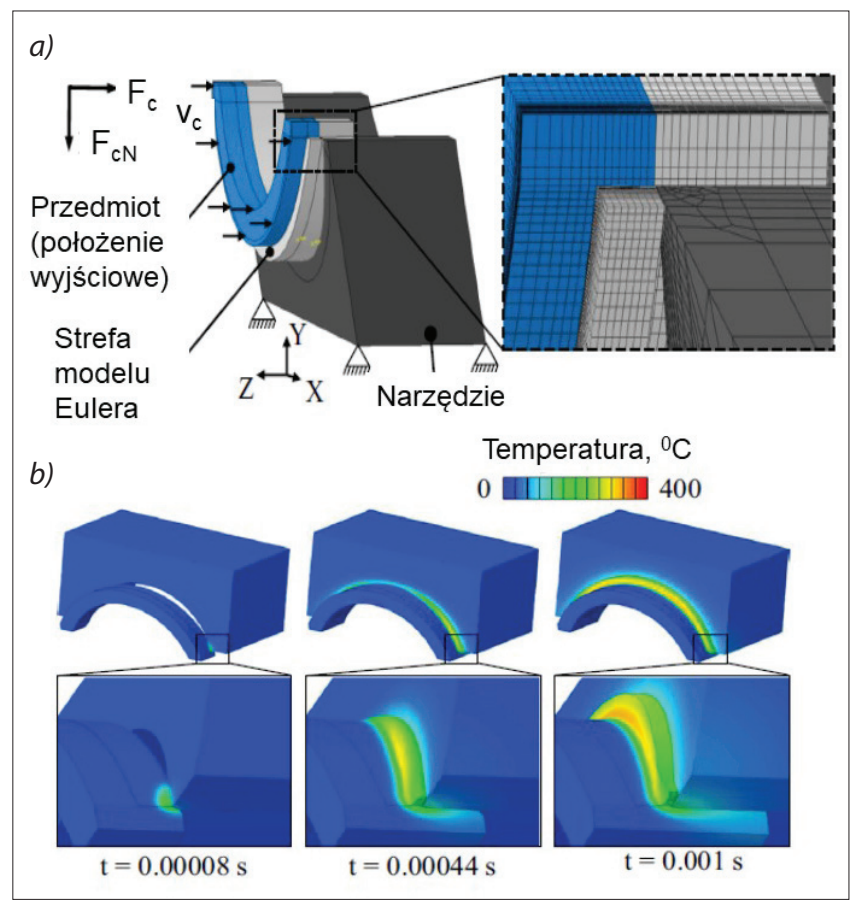

Fig. 6. Concept of the 3D FE model for the finish broaching in ABAQUS Explicit package (a) and simulation of chip formation in finish broaching showing temperature fields $(b)$ for: cutting speed of $v_{\mathrm{c}}=20 \mathrm{~m} / \mathrm{min}$, cutting tool nose radius $r=1 \mathrm{~mm}$, maximum cut thickness $h_{\max }=0.02 \mathrm{~mm}$ [9]

Rys. 6. Koncepcja modelu 3D FE przeciągania wykańczającego wygenerowanego w programie ABAQUS Explicit (a) i symulacja tworzenia wióra z zaznaczonym rozkładem temperatury $(b)$. Warunki obróbki: prędkość skrawania $v_{c}=20 \mathrm{~m} / \mathrm{min}$, promień naroża narzędzia $r=1 \mathrm{~mm}$, maksymalna grubość warstwy skrawanej $h_{\max }=0,02 \mathrm{~mm}[9]$
Na rys. 7 pokazano wyniki symulacji FE dla siły skrawania $F_{\mathrm{c}}$ i siły normalnej $F_{\mathrm{cN}}$ bez wpływu zużycia ostrza (a) i z uwzględnieniem tego wpływu $(b)$. Zwraca uwagę spadek wartości siły $F_{c}$ gdy krawędź skrawająca ostrza ma większy promień zaokrąglenia (po szlifowaniu $r_{\beta}=5 \mu \mathrm{m}$ ). Efekt ten jest bardziej widoczny dla siły normalnej [9]. Z tego względu w przeciąganiu wykańczającym $(h=0,02 \mathrm{~mm})$ należy dokładnie dobrać początkową wartość promienia $r_{\beta}$.

Wynik modelowania wpływu zużycia powierzchni przyłożenia $\left(V B_{\mathrm{B}}=0 \div 30 \mu \mathrm{m}\right)$ przedstawiono na rys. $7 b$. W tym przypadku większy wzrost wartości, prawie pięciokrotny, obserwuje się dla składowej normalnej. Z kolei wzrost wartości siły $F_{\mathrm{c}}$ jest dostrzegalny, ale maksymalnie w zakresie $20 \%$.

W symulacji numerycznej ważnym zagadnieniem pozostaje ustalenie warunków tarcia $[3,10]$. W opisanych symulacjach 3D-FEM stosowano następujący model dla pozornego współczynnika tarcia (przyjęto następujące wartości trzech parametrów: $\mu_{0}=0,46, T_{\mathrm{f}}=200^{\circ}, m_{\mathrm{f}}=2,4$; temperatura topnienia $\left.T_{\mathrm{m}}=1800^{\circ} \mathrm{C}\right)$ :

$$
\mu_{\mathrm{poz}}=\mu_{\mathrm{o}}\left(1-\left(\frac{T-T_{\mathrm{f}}}{T_{\mathrm{m}}-T_{\mathrm{f}}}\right)^{m_{\mathrm{f}}}\right)
$$

W pracy [10] przedstawiono szczegółową analizę wpływu tarcia i mikrostruktury stali o strukturze

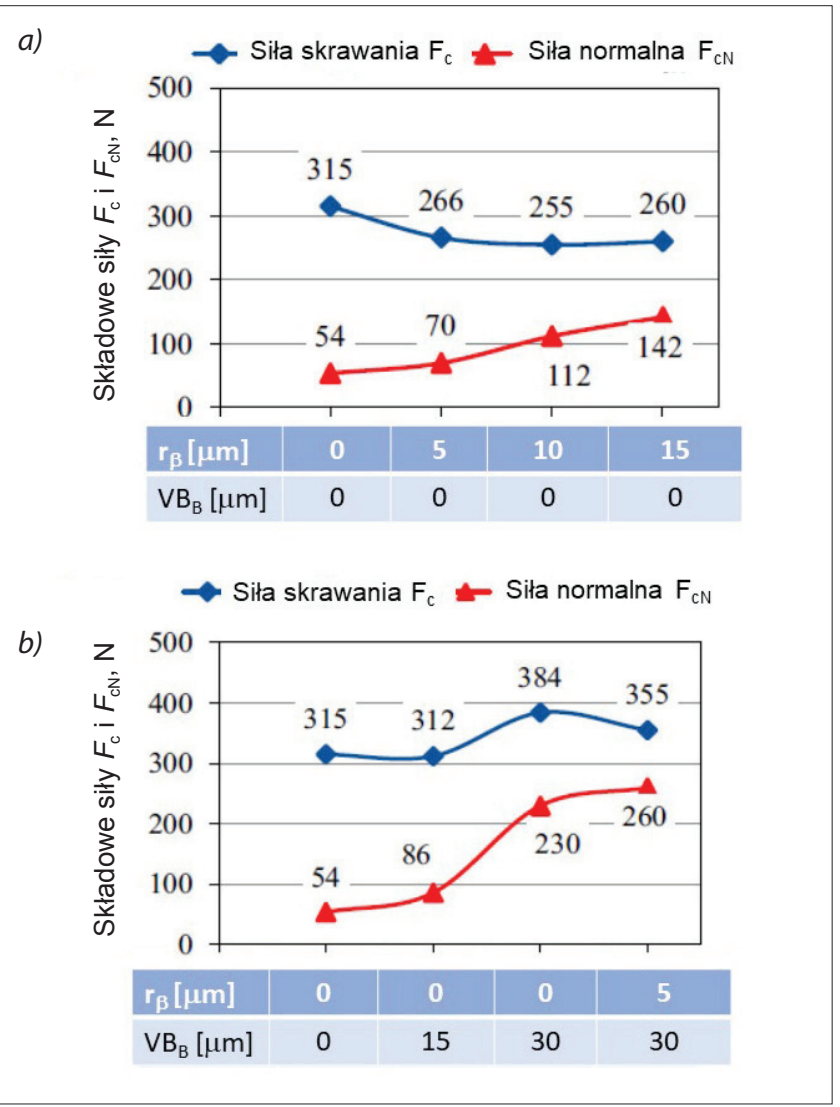

Fig. 7. Results of FE simulation for the influence of cutting edge radius $\left(r_{\beta}\right)(a)$ and flank wear $\left(V B_{B}\right)(b)$ on cutting and normal forces in finish broaching of Inconel 718 alloy [9]. Machining conditions: cutting speed of $v_{c}=20 \mathrm{~m} / \mathrm{min}$, cut thickness $h=0.02 \mathrm{~mm}$

Rys. 7. Wyniki symulacji FEM wpływu promienia zaokrąglenia krawędzi skrawającej $\left(r_{\beta}\right)(a)$ i zużycia ostrza $\left(V B_{B}\right)(b)$ na wartości siły skrawania i siły normalnej w wykańczającym przeciąganiu stopu Inconel 718 [9]. Warunki obróbki: prędkość skrawania $v_{\mathrm{c}}=20 \mathrm{~m} / \mathrm{min}$, grubość warstwy skrawanej $h=0,02 \mathrm{~mm}$ 
perlityczno-ferrytycznej na przebieg procesu przeciagania. W tym celu przeprowadzono specjalne testy tribologiczne na tribometrze typu pin-on-disk (opisane w numerach 2 i 4 Mechanika z 2019 r. [11,12])

a)

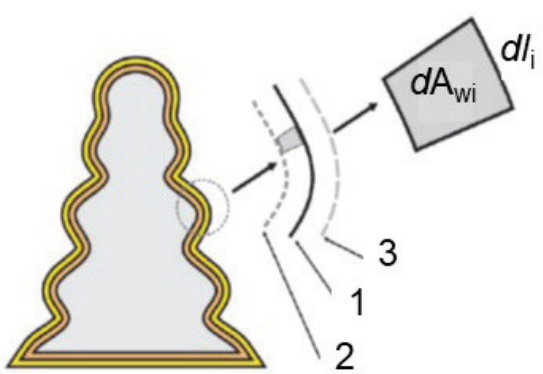

Położenia krawędzi skrawającej:

1 - bieżące, 2 - poprzednie, 3 - następne

b)

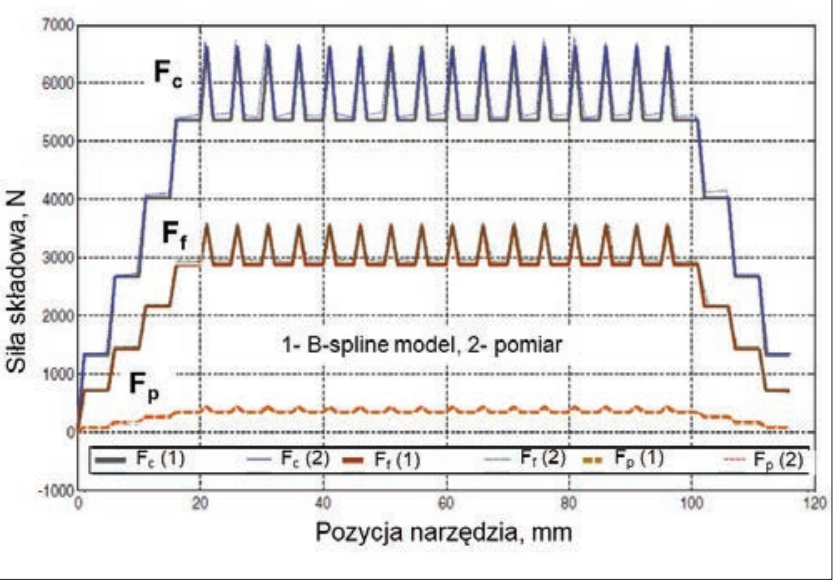

Fig. 8. Definition of infinitesimal element of the undeformed chip area (a) and comparison of simulated and experimental cutting forces for oblique broaching $\left(\lambda_{s}=15^{\circ}\right)(b)$ [13]. Cutting conditions: $I=21 \mathrm{~mm}, b=4 \mathrm{~mm}, f=0.06 \mathrm{~mm} /$ tooth, broaching stroke $I_{\mathrm{p}}=4 \mathrm{~mm}$ Rys. 8. Definicja elementarnego pola przekroju wióra (a) i porównanie symulowanych i zmierzonych wartości sił składowych w ukośnym przeciąganiu $\left(\lambda_{\mathrm{s}}=15^{\circ}\right)(b)$ [13]. Warunki obróbki: $I=21 \mathrm{~mm}$ $b=4 \mathrm{~mm}, f=0,06 \mathrm{~mm} /$ ostrze, skok przeciągania $I_{\mathrm{p}}=4 \mathrm{~mm}$ z zastosowaniem trzpieni bez powłoki i z powłoką TiN oraz dodatkowo ze smarowaniem. Ustalono m.in., że dla trzpienia z powłoką TiN i smarowaniem olejowym pozorny współczynnik tarcia jest praktycznie stały i równy ok. 0,13.

Na rys. 8 przedstawiono rezultat modelowania trzech sił składowych $\left(F_{\mathrm{c}}\left(F_{\mathrm{t}}\right), F_{\mathrm{f}}\right.$ i $\left.F_{\mathrm{p}}\left(F_{\mathrm{r}}\right)\right)$, stosując znane zależności do wyznaczania wartości sił w funkcji składowych oporów skrawania dla skrawania ukośnego. Ze względu na trójwymiarowy proces skrawania $\left(\lambda_{\mathrm{s}}=15^{\circ}\right)$ uwzględniono współczynniki $k_{\mathrm{c}} \mathrm{i} k_{\mathrm{k}}$ odniesione do grubości warstwy skrawanej i długości kontaktu/styku wiór-ostrze dla trzech składowych [13]. Przykładowo: sumowanie obciążeń dla siły skrawania (współczynniki: $k_{\mathrm{cc}}$ i $k_{\mathrm{kc}}$ ) wykonano według zależności:

$$
F_{C}=k_{c c} \int_{i=0}^{l_{s}} h_{i} \times d l_{i}+k_{k c} \int_{i=0}^{l_{s}} d l_{i}
$$

gdzie: $A_{\mathrm{wi}}=h_{\mathrm{i}} \times d l_{\mathrm{i}}$ - elementarne pole przekroju wióra, a $l_{s}$ - długość krawędzi skrawającej.

W sumowaniu obciążeń wzdłuż krawędzi skrawającej zastosowano całkowanie po zarysie krawędzi skrawającej opisane za pomocą interpolacji funkcją typu $B$-spline. W modelowaniu procesu przeciągania stopu Waspalloy przyjęto następujące wartości oporów właściwych skrawania: $k_{\mathrm{cc}}=5398 \mathrm{~N} / \mathrm{mm}^{2}, k_{\mathrm{cf}}=2900$ $\mathrm{N} / \mathrm{mm}^{2}$ i $k_{\mathrm{cr}}=353 \mathrm{~N} / \mathrm{mm}^{2}$. Przyjęta koncepcja modelowania obciążenia daje dobrą zgodność wyników symulacji i pomiaru. Widoczne są okresowe zmiany wartości sił związane z wcinaniem się poszczególnych ostrzy w sekcji.

\section{Projektowanie przeciągaczy specjalnych}

\section{Przeciągacze do rowków w wirnikach turbin}

Jak podano w pierwszej i drugiej części artykułu $[1,2]$, do wykonywania rowków w wirnikach sprężarek i turbin silników odrzutowych stosuje się specjalne

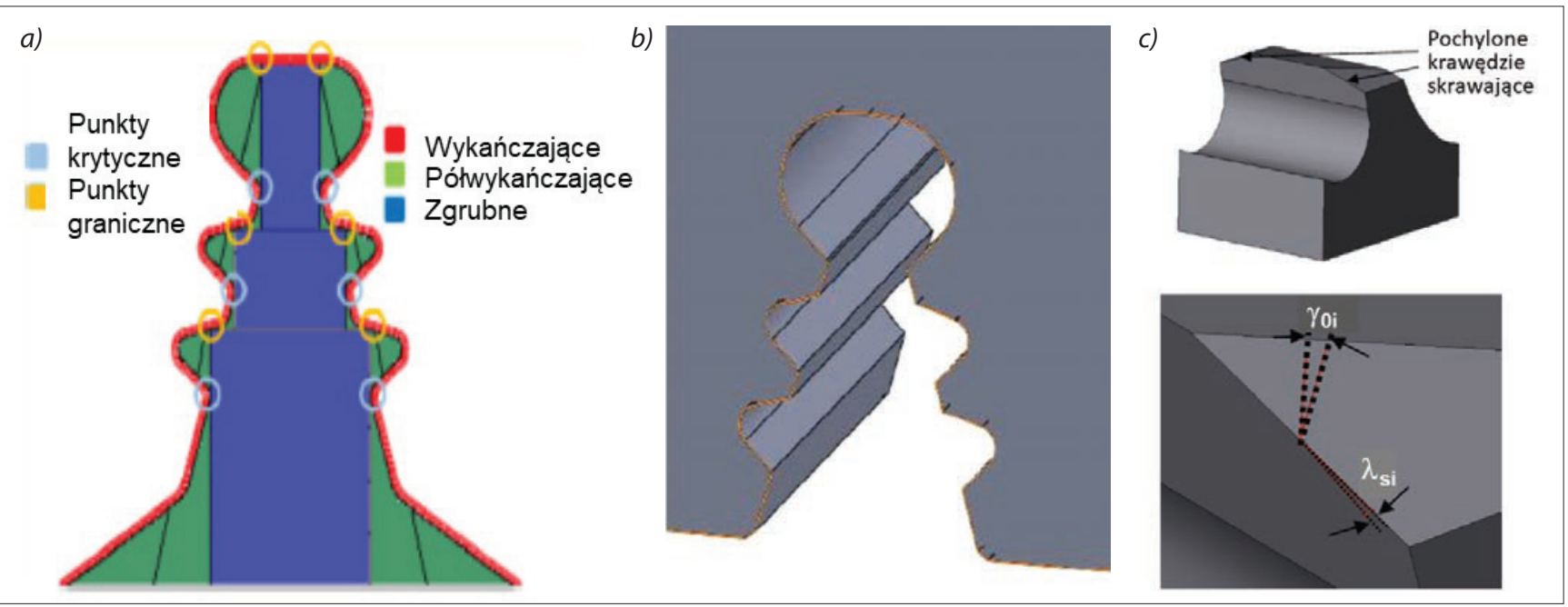

Fig. 9. Distribution of the material allowance in broaching fir/Christmas tree grooves in turbine disks (a), final shape of the groove $(b)$ and a tooth geometry with inclined side cutting edges and local tool angles (c) $[1,14,15]$

Rys. 9. Podział naddatku obróbkowego w przeciąganiu rowków jodełkowych w wirnikach turbin $(a)$, końcowy zarys rowka (b) oraz geometria ostrza z pochylonymi krawędziami bocznymi i definicja lokalnych kątów ostrza $(c)[1,14,15]$ 
przeciągacze na jaskółczy ogon (dovetail type broach) i jodełkowe (fir/Christmas tree broach). Zasadę podziału naddatku obróbkowego w przekroju rowka jodełkowego przedstawiono na rys. $9 a$. Naddatek jest usuwany przez przeciągacz zgrubny, półwykańczający i wykańczający. W projektowaniu narzędzi uwzględnia się materiał obrabiany, długość przeciąganego zarysu oraz charakterystykę przeciągarki.

Projektowanie przeciągaczy do rowków jest złożone, ponieważ zachodzi konieczność uwzględnienia zmian konfiguracji przedmiotu po przejściu każdego ostrza w sekcji (modyfikacji pola przekroju warstwy skrawanej). Dodatkowo należy się liczyć ze zmianą geometrii ostrza wskutek pochylenia krawędzi skrawającej w strefach bocznych, jak na rys. 9c. Z tego względu opracowano specjalny program symulacyjny BOSS (Broaching Operation Simulation Software), który umożliwia wyznaczenie sił, mocy, naprężeń, grubości wióra i rozkładu kąta natarcia dla operacji przeciągania narzędziem złożonym z wielu ostrzy i sekcji $[15,16]$.

W podanym przykładzie uwzględniono projektowanie przeciągacza złożonego z 14 sekcji i 427 ostrzy (fragment narzędzia i usytuowanie ostatnich ostrzy w sekcjach przedstawiono na rys. $10 a-b$ ) [14]. Przeciągano przedmioty ze stopu niklu Waspalloy o długości $20 \mathrm{~mm}$. Schemat podziału naddatku dla całego zarysu rowka oraz zapis widma siły skrawania w czasie skoku roboczego przedstawiono na rys. $11 a$, a usytuowanie ostatnich ostrzy w każdej sekcji po optymalizacji konstrukcji narzędzia przedstawiono na rys. $11 b$. Zarys rowka został aproksymowany funkcją $B$-spline [16]. Przeprowadzone obliczenia umożliwiły uzyskanie informacji o rozkładzie kątów ostrza i składowych sił skrawania, co przełożyło się na istotne zmiany konstrukcji narzędzia (zwłaszcza ograniczenie liczby ostrzy i punktów krytycznych zaznaczonych

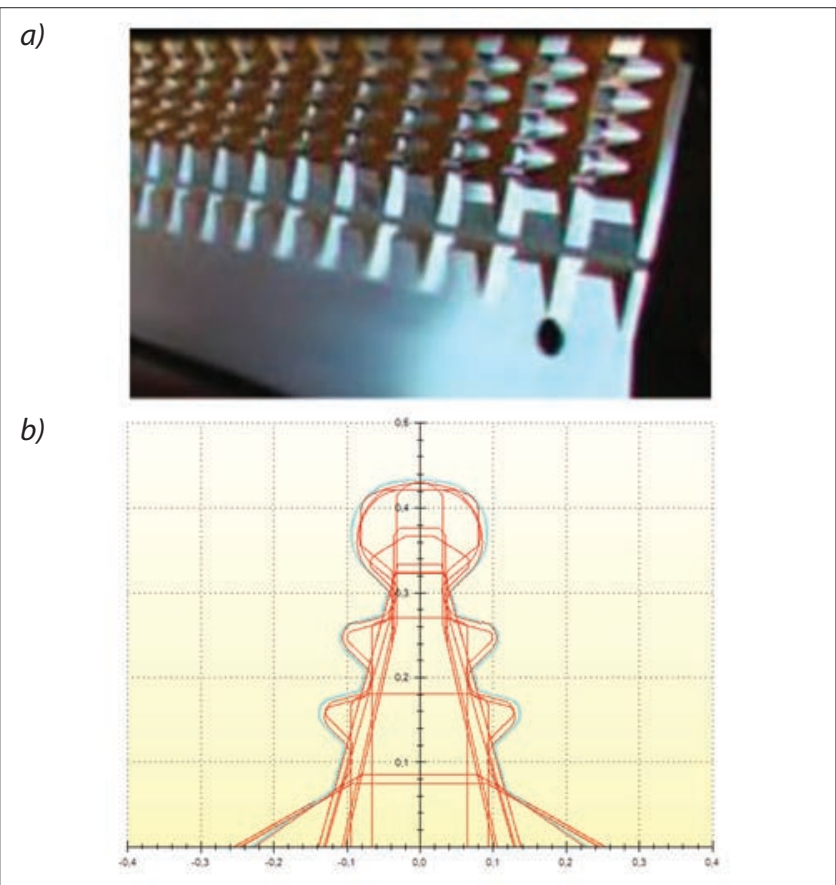

Fig. 10. View of the broach (a) and the projection of last tooth of each section of the broach $(b)[14,15]$

Rys. 10. Widok przeciągacza (a) i usytuowanie ostatniego ostrza z każdej sekcji $(b)[14,15]$ na rys. 9a). Wyniki projektowania można wizualizować w dostępnym graficznym interfejsie użytkownika [16].

$\mathrm{Na}$ podstawie informacji literaturowych $[14,15]$ można stwierdzić, że dzięki optymalizacji konstrukcji przeciągacza do rowków jodełkowych w zakładach P\&W Canada zmniejszono liczbę ostrzy o 38\%, a długość przeciągacza skrócono o ok. 25\% wskutek zmniejszenia liczby jednocześnie pracujących ostrzy i ich obciążenia. Wszystkie parametry geometryczne wprowadzane do programu jako dane wejściowe lub wyznaczone z odpowiednich algorytmów są eksportowane $\mathrm{w}$ formie sparametryzowanego modelu bryłowego. Ułatwia to wygenerowanie modelu narzędzia w programie CAD, który może być już przydatny do jego wykonania. Optymalizacja technologiczna zakłada utrzymanie granicznej wartości obciążenia dla maksymalnego przyrostu grubości warstwy skrawanej na ostrze w każdej sekcji. Możliwa jest także optymalizacja podziałki ostrzy (obecnie projektant wprowadza stałą wartość podziałki). W projektowaniu korzysta się z bazy danych wartości oporu właściwego skrawania dla różnych materiałów konstrukcyjnych [16].

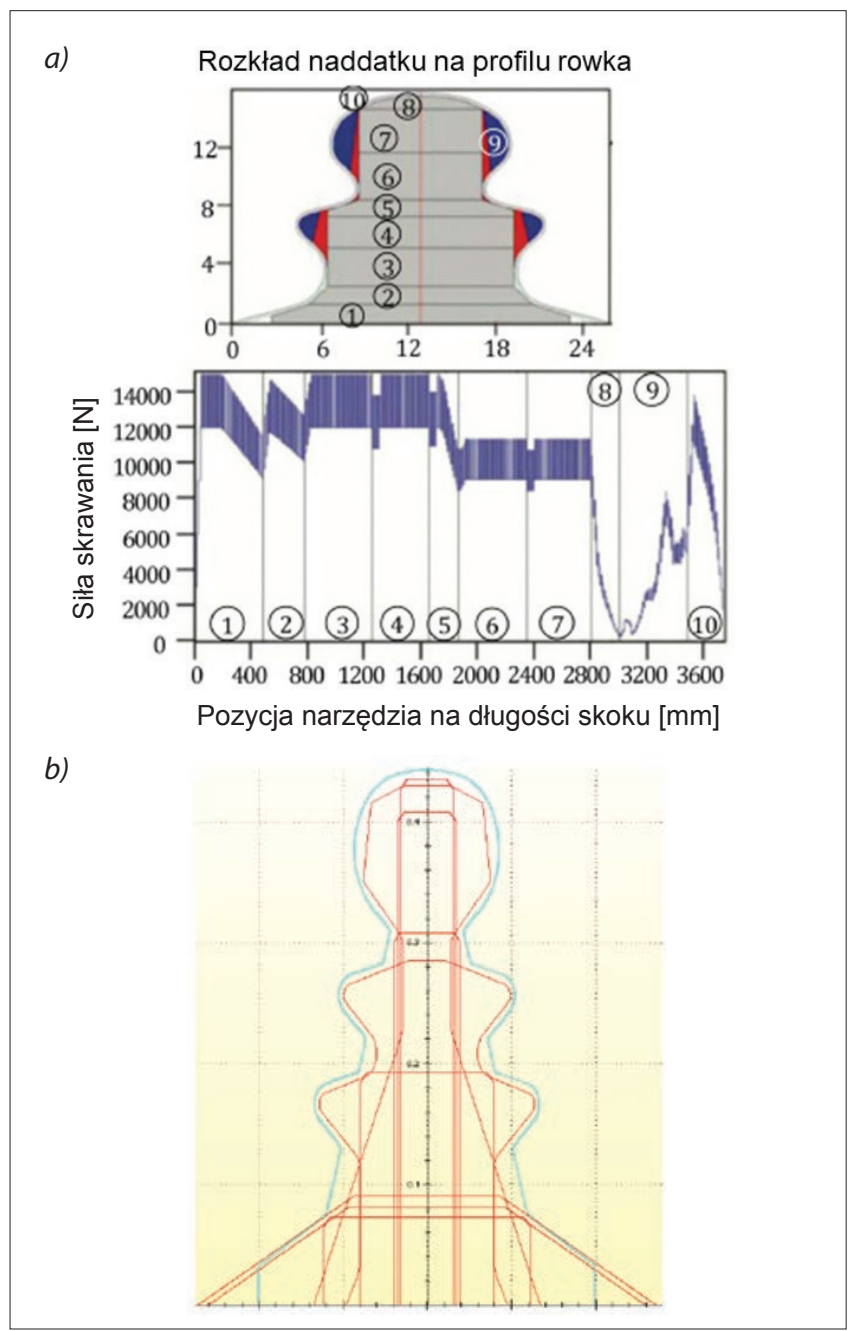

Fig. 11. Change of cutting force values for subsequent cutting edges of fir/Christmas tree broach in one stroke $(a)$ and distribution of the cutting edges for optimized broach $(b)[3,14-16]$

Rys. 11. Zmiana wartości siły skrawania dla kolejnych ostrzy przeciągacza do rowków jodełkowych w jednym skoku $(a)$ i rozkład ostrzy dla optymalizowanej konstrukcji $(b)[3,14-16]$ 
Rozwój narzędzi do przeciągania i zwiększenie wydajności procesu wiąże się ściśle z wprowadzaniem nowych materiałów narzędziowych i nakładaniem specjalnych powłok.

\section{LITERATURA}

[1] Grzesik W. "Development in broaching technology. Part I. Development of broaching machines and tooling devices” [„Postęp w obróbce przeciąganiem. Część I. Rozwój przeciągarek i oprzyrządowania narzędziowego"]. Mechanik. 5-6 (2021): 6-11, https://doi.org/10.17814/mechanik.2021.5-6.8.

[2] Grzesik W. "Development in broaching technology. Part II. Development of broaching methods and tooling devices on CNC machine tools“ [„Postęp w obróbce przeciaganiem. Część II. Rozwój sposobów przeciągania i oprzyrządowania narzędziowego na obrabiarkach CNC"]. Mechanik 8-9 (2021): 6-12, https://doi.org/10.17814/mechanik. 2021.8-9.12.

[3] Arrazola J.P., Rech J., M'Saoubi R., Axinte D. "Broaching: Cutting tools and machine tools for manufacturing high quality features in components". CIRP Annals Manufacturing Technology. 69, 2 (2020): 554-577, https://doi. org/10.1016/j.cirp.2020.05.010.

[4] Olszak W. „Obróbka skrawaniem”. Warszawa: PWN (2017).

[5] Toenshoff H.K., Denkena B. "Basic of Cutting and Abrasive Processes". Heidelberg: Springer (2013).

[6] Grzesik W. „Podstawy skrawania materiałów konstrukcyjnych". Warszawa: PWN (2018).

[7] Kishawy H.A., Hosseini A., Moetakef-Imani B., Astakhov V.P. "An energy based analysis of broaching operation: Cutting forces and resultant surface integrity". CIRP Annals Manufacturing Technology. 61, 1 (2012): 107-110, https://doi.org/10.1016/j.cirp.2012.03.004.

[8] Vogtel P., Klocke F., Puls H., Buchkremer S., Lung D. "Modelling of process forces in broaching Inconel 718". Procedia CIRP. 8 (2013): 409-414, https://doi.org/10.1016/ j.procir.2013.06.125.

[9] Seimann M., Peng B., Fischersworring-Bunk A., Rauch S. Klocke F., Doebbeler B. "Model-based analysis in finish broaching of Inconel 718". Int. J. Adv. Manuf. Technol. 97 (2018): 3751-3760, https://doi.org/10.1007/s00170018-2221-5.

[10] Courbon C., Arrieta I.M., Cabanettes F., Rech I., Arrazola P.J. "The contribution of microstructure and friction in broaching Ferrite-Pearlite steels". CIRP Annals Manufacturing Technology. 69, 1 (2020): 57-60, https://doi.org/10.1016/j.cirp.2020.04.023.

[11] Grzesik W., Rech J. "Influence of machining conditions on friction in metal cutting process. A review". Mechanik 92, 4 (2019): 242-248, https://doi.org/10.17814/mechanik.2019.4.33.

[12] Grzesik W. "Methods and devices for measuring metal cutting friction and wear". Mechanik. 92, 2 (2019): 85-89, https://doi.org/10.17814/mechanik.2019.2.16.

[13] Hosseini A., Kishawy H.A. "Prediction of cutting forces in broaching operation, J. Advanced Manufacturing Systems. 12, 1 (2019): 1-14, https://doi.org/10.1142/ S0219686713500017.

[14] Őzlu E., Engin S., Cook C., El-Wardany T., Budak E. "Simulation of broaching operations for tool design optimization". Proc. $2^{\text {nd }}$ Conf. on Process Machine Interactions, Vancouver, Canada (2010).

[15] Őzlu E., Araghizad A.E., Budak E. "Broaching tool design through force modelling and process simulation". CIRP Annals Manufacturing Technology. 69, 1 (2020): 53-56, https://doi.org/10.1016/j.cirp.2020.04.035.

[16] Vogtel P., Klocke F., Lung D., Terzi S. "Automatic broaching tool design by technological and geometrical optimization". Procedia CIRP. 33 (2015): 496-501, https://doi.org/ 10.1016/j.procir.2015.06.061. 